\title{
Pengambilan Keputusan Normatif KPU: Perspektif Menghadapi Pragmatisme Partai Politik pada Pencalonan Kepala Daerah Karanganyar Tahun 2018
}

Siti Fadhilah ${ }^{1}$

\begin{abstract}
Abstrak
Artikel ini mengungkap dinamika dalam pengambilan keputusan KPU Karanganyar ketika menerima pendaftaran pasangan calon pada Pilkada Karanganyar 2018. Salah satu pasangan calon diusung oleh Partai Keadilan Sejahtera (PKS) dan Partai Gerindra, padahal sebelumnya Partai Gerindra telah mengusung pasangan calon lain. Saat mendaftarkan pasangan calon lagi, dukungan Partai Gerindra terhadap pasangan calon lain sebelumnya belum dicabut. Pendekatan yang digunakan dalam penelitian ini adalah studi kasus, yaitu dengan menggali informasi melalui wawancara, pengumpulan, dan pendokumentasian data dari KPU Karanganyar. Hal tersebut dilakukan agar berhasil mendeskripsikan respons KPU Karanganyar saat menghadapi sikap pragmatis partai politik dalam pencalonan kepala daerah. Dari penelitian ini, diketahui bahwa meskipun Partai Gerindra tidak mencabut dukungan pada pasangan calon yang diusung sebelumnya, KPU Karanganyar melalui langkah-langkah srategis memutuskan untuk menerima pendaftaran pasangan calon Rohadi-Ida. Dapat disimpulkan bahwa keputusan tersebut menunjukkan bukti nyata bahwa KPU Karanganyar telah membuat keputusan berdasarkan pada norma-norma yang berlaku dan sesuai dengan aturan main pemilu. Pengalaman KPU Karanganyar tersebut dapat menjadi acuan yang bermanfaat bagi penyelenggaraan pilkada di daerah lain pada pilkada di masa mendatang, bilamana penyelenggara pilkada menghadapi sikap pragmatis partai politik ketika mengusung pasangan calon kepala daerah.
\end{abstract}

Kata Kunci: Keputusan; KPU; Pencalonan; Pilkada

1 Mahasiswa Pascasarjana pada Program Studi Tata Kelola Pemilu, Universitas Gadjah Mada. 


\section{PENDAHULUAN}

Pilkada serentak tahun 2018 yang diselenggarakan pada 27 Juni 2018 diikuti oleh 171 daerah, terdiri dari 17 provinsi, 115 kabupaten, dan 39 kota yang tersebar di seluruh wilayah Indonesia. Kabupaten Karanganyar merupakan salah satu daerah yang menyelenggarakan pilkada pada tahun 2018. Salah satu fenomena yang terjadi dalam pilkada adalah pecah kongsi petahana. Menurut penelitian yang dilakukan oleh Kementrian Dalam Negeri bahwa pada pilkada serentak 2018 di tingkat kabupaten, petahana bupati yang maju tercatat 67 orang, sedangkan wakil bupati yang maju sebanyak 54 orang. Di tingkat kota, terdapat 25 petahana walikota dan 25 petahana wakil walikota yang maju kembali. Rata-rata dari kepala daerah petahana dan wakilnya pecah kongsi, maju sendiri-sendiri di periode keduanya. ${ }^{2}$ Ketidakharmonisan selama menjalankan roda pemerintahan bukan satu-satunya penyebab terjadinya pecah kongsi. Harga diri dan kepentingan pragmatisme partai juga menjadi penyebab dari pecah kongsi (Bumi, 2016).

Pilkada Karanganyar 2018 pun tidak dapat menghindari fenomena pecah kongsi antara bupati petahana dan wakil bupati petahana. Pecah kongsi itu menyebabkan pendukung calon bupati petahana mendapatkan dukungan lebih kuat dari partai politik tingkat Kabupaten Karanganyar. Sedangkan wakil bupati petahana yang mencalonkan diri

2 https://www.kemendagri.go.id/berita/baca/16288/banyak-pasangan-petahana-yang-pecahkongsi. 
sebagai calon bupati kurang mendapatkan dukungan dari partai politik di Kabupaten Karanganyar.

Ketentuan tentang peserta pemilihan kepala daerah dan syarat pencalonan diatur dalam Peraturan KPU Nomor 3 Tahun 2017 tentang Pencalonan Pemilihan Gubernur dan Wakil Gubernur, Bupati dan Wakil Bupati, dan/ atau Walikota dan Wakil Walikota. ${ }^{3}$ Sebagai syarat pencalonan pada Pilkada Karanganyar 2018, untuk mengusung pasangan calon kepala daerah minimal diusung sembilan kursi di DPRD.

Pada saat pendaftaran pasangan calon, sampai dengan batas waktu hari terakhir pendaftaran hanya terdapat satu pasangan calon bupati dan wakil bupati yang mendaftar, dengan diusung oleh koalisi partai dengan jumlah 39 kursi. Akibatnya, KPU Karanganyar menunda sementara tahapan pilkada guna membuka perpanjangan pendaftaran.

Sisa kursi yang ada di DPRD adalah enam kursi sehingga untuk mengusung satu pasangan calon tidak mencukupi dan tidak dapat dilakukan. Kecuali, ada satu atau lebih partai politik yang mencabut atau menarik dukungan terhadap pasangan calon yang mendaftar pada saat pendaftaran sebelumnya agar jumlah kursi dapat memenuhi syarat

3 Ketentuan Peraturan KPU Nomor 3 Tahun 2017 tentang Pencalonan Pemilihan Gubernur dan Wakil Gubernur, Bupati dan Wakil Bupati, dan/atau Walikota dan Wakil Walikota menyebutkan bahwa peserta pemilihan adalah pasangan calon yang diusulkan oleh partai politik dan atau gabungan partai politik dan telah memenuhi syarat untuk ditetapkan sebagai peserta pemilihan, dan/ atau pasangan calon perseorangan yang mendaftarkan diri dan telah memenuhi syarat untuk ditetapkan sebagai peserta pemilihan, sedangkan dalam Pasal 5 ayat (4) mengatur tentang syarat pencalonan, yakni jumlah kursi Dewan Perwakilan Rakyat Daerah hasil pemilu terakhir x 20\% (dua puluh persen) dan syarat pencalonan adalah jumlah seluruh suara sah hasil pemilu terakhir x 25\% (dua puluh lima persen). 
pencalonan untuk mengusung satu pasangan calon bupati dan wakil bupati.

Pada masa perpanjangan pendaftaran, salah satu partai pengusung pasangan calon bupati dan wakil bupati Karanganyar yang telah terlebih dulu mendaftar yaitu Partai Gerindra kemudian mengusung pasangan calon lain. Hal ini awalnya memunculkan dilema bagi KPU Karanganyar dalam menerima pendaftaran pasangan calon bupati dan wakil bupati yang diusung, karena Partai Gerindra pada saat mengusung pasangan calon lain tanpa mencabut dukungan sebelumnya.

Fenomena ini cukup menarik karena ada drama baru dalam dunia politik. Perubahan komposisi partai pengusung pasangan calon kepala daerah pada masa perpanjangan pendaftaran tidak banyak terjadi. Fenomena perubahan komposisi partai pengusung pasangan calon pada Pilkada 2018 hanya terjadi di dua Kabupaten/Kota di Indonesia, yaitu di Kabupaten Karanganyar dan Kabupaten Jayawijaya. Saat itu, pada Pilkada Jayawijaya 2018 Partai Nasdem dan Partai Golkar telah mengusung pasangan calon Jhon Richard Banua SE, M.Si-Marthin Yogobi SH, M.Hum pada masa pendaftaran, kemudian mengusung lagi pasangan calon Maikel Kogoya-Andias Tabumi pada masa perpanjangan pendaftaran. Bedanya, status pendaftaran bakal pasangan calon bupati dan wakil bupati Karanganyar 2018 dinyatakan diterima oleh KPU, sedangkan pendaftaran bakal pasangan calon bupati dan wakil bupati Jayawijaya di masa perpanjangan pendaftaran dinyatakan ditolak oleh KPU, ${ }^{4}$ karena sampai dengan satu hari sebelum hari

4 Sumber diperoleh dari https://infopemilu.kpu.go.id/pilkada2018. 
terakhir perpanjangan pendaftaran dokumen persyaratan dinyatakan tidak lengkap. ${ }^{5}$

Fenomena yang hampir sama pernah terjadi pada pilkada tahun 2017 di Kabupaten Pringsewu. Pecah koalisi pada Pilkada Pringsewu 2017 mengakibatkan batalnya pencalonan Ririn Kuswantari karena perubahan parpol pengusung, yang akhirnya parpol pengusungnya tidak memenuhi ambang batas pencalonan (Mayasari, 2018). Perbedaan dengan fenomena yang terjadi di Karanganyar adalah pecah koalisi di Kabupaten Pringsewu terjadi sebelum dilakukan pendaftaran ke KPU, sehingga tidak terlalu signifikan terhadap kebijakan dari KPU Kabupaten Pringsewu.

Pada Pilkada Karanganyar 2018, perubahan komposisi parpol pengusung (koalisi) terjadi pada saat pasangan calon telah diterima pendaftarannya. Untuk itu, penelitian ini diharapkan dapat memberikan gambaran ketika KPU selalu dituntut untuk mengambil keputusan yang tepat sebagaimana telah diatur dalam Undang-undang atau peraturan terkait. Karena keputusan KPU Kabupaten/ kota merupakan penjabaran dari peraturan perundang-undangan yang berlaku, kebijakan KPU RI, dan KPU Provinsi, namun untuk mengimplementasikan kebijakan dimaksud, bukan hal yang mudah. Kebijakan merupakan sesuatu yang kompleks dan keputusan merupakan bagian dari kebijakan tersebut.

KPU Kabupaten/Kota dalam hal pencalonan (kandidasi) memiliki wewenang untuk menentukan kebijakan dan keputusan termasuk

5 https://www.ceposonline.com/2018/01/20/ini-alasan-kpu-jayawijaya-kembalikan-berkaspaslon/ 
dalam menghadapi pragmatisme partai politik pada saat pembentukan koalisi partai pengusung pasangan calon yang tidak berimbang, sehingga dapat mengurangi ataupun menghilangkan peluang pasangan calon lain untuk ikut dalam kontestasi.

Berikut beberapa penelitian yang memiliki relevansi dengan fokus kajian penelitian ini, antara lain kajian yang ditulis oleh Drs. Mursalim Massuanna dan Risma Niswaty, SS., M.Si. (2012) yang bertujuan untuk mengetahui implementasi kebijakan pencalonan pada pemilihan kepala daerah dan wakil kepala daerah tahun 2010 di Kabupaten Gowa. Dengan menggunakan metode deskriptif kualitatif, hasil penelitiannya menunjukkan bahwa permasalahan yang muncul dalam tahapan pencalonan ini salah satunya adalah adanya parpol yang mengusung dua calon berbeda oleh dua pengurus yang berbeda. Permasalahan ini termasuk dalam konflik intraparpol yang perlu mendapatkan penanganan serius dari lembaga penyelenggara pemilu. Langkah yang ditempuh KPU adalah melakukan verifikasi faktual untuk membuktikan keabsahan surat-surat pencalonan dan legalitas pengurus partai politik sehingga dapat dijadikan pedoman bagi KPU untuk memutuskan pasangan calon mana yang diterima pendaftarannya.

Kajian yang berkaitan dengan perubahan komposisi partai pengusung pasangan calon kepala daerah pernah ditulis oleh Ulfa Umayasari (2018), yang bertujuan untuk mengetahui dinamika pencalonan Ririn Kuswantari yang semula dicalonkan melalui kesepakatan bersama oleh koalisi Partai Golkar dan PPP Kabupaten 
Pringsewu pada Pilkada 2017, namun berujung pembatalan karena PPP menarik dukungan terhadap calon bupati Ririn karena calon wakil bupati yang diajukan bukan dari PPP melainkan dari PAN. Dengan menggunakan metode deskriptif kualitatif, hasil penelitiannya menunjukkan bahwa pencalonan Partai Golkar batal didaftarkan ke KPU karena syarat minimal untuk mengusung pasangan calon bupati dan wakil bupati di Kabupaten Pringsewu tidak terpenuhi.

Sementara itu, kajian yang membicarakan kebijakan politik ditulis oleh Pratiwi Tejdo (2019) mengidentifikasi permasalahan dalam penegakan demokrasi, khususnya dalam konteks kebijakan publik yang dilahirkan dari keputusan-keputusan politik. Dengan menggunakan studi literatur, kajian ini menunjukkan bahwa jika politik dianggap terdiri dari keputusan-keputusan kolektif, itu dianggap wajar karena semua keputusan yang sifatnya politis merupakan keputusan kolektif yang bersifat politis. Lebih lanjut, Tedjo (2019) memandang kebijakan publik merupakan keputusan politik yang dikembangkan oleh badan dan pejabat pemerintah. Karena itu, karakteristik khusus dari kebijakan publik adalah bahwa keputusan politik dirumuskan oleh otoritas pada sistem politik dalam rangka memformulasikan kebijakan publik.

Melihat referensi di atas, penelitian yang ada hanya membahas tentang perubahan komposisi partai pengusung pasangan calon sebelum mereka mendaftarkan diri ke KPU. Sedangkan penelitian yang membahas tentang perubahan komposisi partai yang terjadi pada masa perpanjangan pendaftaran belum banyak dilakukan. Untuk itu, penting dilakukan pengkajian/penelitian tentang perubahan komposisi partai 
pengusung pasangan calon kepala daerah yang dilakukan di masa perpanjangan pendaftaran, sekaligus untuk mengetahui bagaimana respons KPU dalam menyelesaikan polemik tersebut. Hal ini penting, karena KPU sebagai salah satu organisasi pemerintah harus selalu siap untuk menghadapi fenomena-fenomena politik yang disebabkan oleh sikap pragmatis partai politik. Termasuk perubahan komposisi parpol pengusung kepala daerah yang berlangsung sangat cepat.

Jika terjadi perubahan komposisi partai pengusung pasangan calon kepala daerah yang dilakukan pada saat perpanjangan pendaftaran, maka keputusan yang tepat dalam kacamata regulasi semestinya diambil untuk memecahkan masalah. Oleh karena itu, kajian ini diharapkan dapat memberikan jawaban bilamana terjadi perubahan komposisi partai politik pengusung pasangan calon kepala daerah pada pilkada periode berikutnya serta dapat menjadikan khazanah ilmu baru dalam dunia politik Indonesia, terutama dalam bidang pengambilan keputusan yang berpengaruh pada kehidupan politik.

Secara khusus, penelitian ini membahas tentang (1) Bagaimana respons KPU Karanganyar dalam menghadapi perubahan komposisi partai pengusung pasangan calon bupati dan wakil bupati Karanganyar 2018? (2) Apakah keputusan KPU Karanganyar telah sesuai dengan peraturan perundang-undangan? Selanjutnya, pengumpulan data di sini menggunakan teknik dokumen, laporan, dan wawancara. Wawancara mendalam dilakukan kepada KPU Kabupaten Karanganyar sebagai penyelenggara Pilkada Karanganyar 2018. Sedangkan teknik analisis data yang dipakai adalah teknik analisis data kualitatif, yaitu semua 
data dikumpulkan kemudian diolah, dianalisis, dan dikonstruksi secara menyeluruh. Langkah selanjutnya setelah data diolah adalah melakukan interpretasi data untuk menarik kesimpulan dari kenyataan yang ditemui. Uraian dan kesimpulan dalam menginterpretasikan data hasil penelitian akan dihubungkan dengan teori-teori, pendapatpendapat, dan aturan-aturan formal yang telah dikemukakan pada bagian sebelumnya.

\section{SIKAP PRAGMATIS PARTAI POLITIK DALAM PENCALONAN KEPALA DAERAH}

Di Indonesia, perilaku pragmatis partai poltik dalam pencalonan kepala daerah telah terjadi sejak tahun 2005 ketika pilkada langsung digelar pertama kali. Arya Budi (2020) menguraikan fenomena rekrutmen calon kepala daerah di Indonesia pada dua partai besar, yakni Partai Golkar dan PDI Perjuangan. Menggunakan analisis rekrutmen pencalonan kepala daerah di Indonesia sejak tahun 2005 sampai dengan tahun 2020, Arya Budi mengungkapkan bahwa proses pencalonan kepala daerah yang diusung oleh Partai PDI Perjuangan dan Partai Golkar dilakukan dengan tidak demokratis, tetapi lebih ditentukan oleh sikap pragmatis parpol, yakni diputuskan oleh pimpinan parpol tingkat pusat. Hal tersebut bertepatan dengan kepemimpinan partai politik yang berkelanjutan dari patron partai yang tak tertandingi. Fenomena seperti ini telah terjadi sejak pertama pilkada dilakukan secara langsung tahun 2005. 
Dalam penelitiannya, Arya Budi melihat proses kandidasi intrapartai politik terbesar di Indonesia (Golkar dan PDIP) dengan hasil bahwa proses kandidasi pada dua partai besar tersebut mengalami krisis demokrasi sejak pilkada dilaksanakan secara langsung tahun 2005 sampai tahun 2020. Proses rekrutmen calon pemimpin daerah kedua partai tersebut cenderung lebih terpusat meskipun pengaturan konstitusional dan institusional mendukung demokratisasi dan desentralisasi. Pencalonan yang diambil alih oleh parpol tingkat pusat (sentralisasi) menurutnya dapat menghasut konflik internal dan memperburuk fraksionalisme partai tingkat lokal (Budi, 2020).

Dalam konteks lain, perilaku pragmatis partai politik terjadi pada Pilkada Serang Tahun 2015, Sayuda Anggoro Wati (2016) mengungkapkan praktik dominasi partai pengusung dalam Pilkada Serang tahun 2015 dan hegemoni kekuasaan yang dilakukan demi tercapainya kemenangan dalam Pilkada membuat berbagai macam persepsi masyarakat. Dominasi partai pengusung marak dilakukan karena tidak adanya regulasi yang mengatur tentang praktik borong partai tersebut. Hal ini memperkuat pandangan bahwa dalam proses rekrutmen kepala daerah intrapartai memang belum sepenuhnya dilakukan secara demokratis, lebih ke pragmatis.

Sikap pragmatisme yang dilakukan partai politik tersebut menuai beberapa polemik, terutama apabila menyangkut keputusan yang harus segera diputuskan oleh KPU sebagai penyelenggara pemilu. Dalam satu kasus, perubahan partai pengusung pernah terjadi pada Pilkada Pati Tahun 2017 (Hermayanti, 2018) menyebutkan dinamika pencalonan 
kepala daerah di Kabupaten Pati dilakukan oleh DPC PDIP Kabupaten Pati dengan DPP Pusat PDI Perjuangan menimbulkan konflik di antara bakal calon yang memperoleh rekomendasi dari pusat, yang kemudian bergabung membentuk relawan kotak kosong. Dari kasus tersebut, KPU Kabupaten Pati pada akhirnya memutuskan untuk menyelenggarakan pilkada dengan satu pasangan calon (pilkada calon tunggal).

Pada dasarnya, fenomena perubahan komposisi partai pengusung pasangan calon merupakan perwujudan dilematika partai politik dalam memaknai demokrasi intrapartai. Demokrasi intrapartai menjadi payung dari model kandidasi yang demokratis ${ }^{6}$ karena demokrasi intrapartai mencerminkan pola relasi kuasa yang setara di antara aktor-aktor di dalam sebuah partai politik. Demokrasi intrapartai merupakan "karakter distribusi atas kekuasaan dalam pembuatan keputusan antara anggota dan pemimpin di dalam sebuah partai politik yang didasarkan pada prinsip inklusivitas dan desentralisasi,"” dimana satu pihak mendukung konsep tersebut dan pihak lain tidak setuju.

Dalam konteks lain, perilaku pragmatis partai politik juga tampak dalam aksi borong partai yang memancing pecah koalisi sehingga menimbulkan perubahan komposisi partai pengusung seperti yang terjadi di Kabupaten Karanganyar. Hal ini menjadi bukti bahwa

6 Mada Sukmajati. Kandidasi dalam Partai Politik di Indonesia. https://www.academia.edu/ 37338642/kandidasi_dalam_partai_politik_di_indonesia. Hal 2.

7 Aurel Croissant dan Paul Chambers (2008). "Intra-Party Democracy in Thailand" dalam Mada Sukmajati. Kandidasi dalam Partai Politik Indonesia. https://www.academia. edu/37338642/ kandidasi_dalam_partai_politik_di_indonesia. 
minimnya pengaturan tentang praktik borong partai pada pencalonan kepala daerah menimbulkan dilema bagi penyelenggara pemilu itu sendiri.

Namun begitu dan pada dasarnya, problematika seperti ini tidak perlu terjadi apabila partai politik mampu melaksanakan kandidasi dengan baik. Sesuai dengan prinsip-prinsip pemilu, proses kandidasi harus bejalan dengan inklusif, bebas, adil, dan kompetitif. Inklusif merujuk pada kesempatan yang sama bagi semua orang yang telah layak untuk menjadi kandidat atau penyeleksi kandidat (selektor). Dengan demikian, semakin inklusif kandidat dan selektor, semakin demokratis pula proses kandidasi. Bebas berhubungan dengan hak dan kesempatan anggota partai untuk memilih kandidat dan dipilih sebagai selektor. Semakin bebas anggota partai menjadi kandidat dan selektor, semakin demokratis pula proses kandidasi. Sedangkan adil, itu terkait dengan perlakuan yang sama untuk semua pihak terutama para kandidat. Semakin adil para kandidat diperlakukan maka semakin demokratis pula proses kandidasi tersebut. ${ }^{8}$

Di Kabupaten Karanganyar, dalam sejarah pilkada sejak diselenggarakan secara langsung tahun 2005, pilkada tahun 2018 merupakan pilkada ketiga yang diselenggarakan oleh KPU Karanganyar untuk memilih bupati dan wakil bupati. Pada pilkada tahun 2008 dapat diselesaikan dengan baik dan lancar berkat peran serta seluruh stakeholder dan seluruh lapisan masyarakat. Pada pilkada tahun

8 Mada Sukmajati. Kandidasi dalam Partai Politik di Indonesia. https://www.academia. edu/37338642/ kandidasi_dalam_partai_politik_di_indonesia. Hal 6-7. 
2013, meskipun sempat diwarnai keributan pada saat pendaftaran pasangan calon perseorangan Kondang Pranoto-Ir. Hartono, hal itu tidak menjadi masalah serius karena pasangan calon yang "ngamuk" pada saat itu dinyatakan tidak memenuhi syarat dukungan pasangan calon perseorangan. ${ }^{9}$ Pada pilkada Karanganyar tahun 2018, sebuah fenomena baru terjadi pada tahapan pencalonan. Terjadi perubahan komposisi partai pengusung pasangan calon pada saat perpanjangan pendaftaran.

Sebelumnya, pencalonan bupati dan wakil bupati Karanganyar dari jalur partai politik diwarnai dengan desas-desus calon bupati petahana akan "selingkuh" dan berpaling dengan calon wakil bupati yang dipilih oleh koalisi pendukungnya. Hal ini bukan isapan jempol belaka, pecah kongsi antara calon bupati dan wakil bupati petahana benar terjadi. Bupati petahana, Juliyatmono kembali maju dalam Pilkada Karanganyar untuk periode 2018-2023. Juliyatmono yang diusung Partai Golkar berpasangan dengan Rober Christanto, kader Partai Demokrasi Indonesia Perjuangan (PDIP). Pasangan calon ini mendaftarkan diri menjadi calon bupati dan wakil bupati ke KPU Karanganyar pada hari Rabu tanggal 10 Januari 2018. Mereka berangkat bersama-sama dari kediaman Juliyatmono di Dusun Pokoh, Kecamatan Tasikmadu dengan kawalan seribuan kader dan simpatisan dari partai politik pengusung. ${ }^{10}$

9 Informasi diperoleh saat wawancara dengan Kasubbag Hukum KPU Karanganyar Smaragung Wibowo tanggal 10 Desember 2019.

10 https://www.merdeka.com/politik/didukung-8-partai-bupati-juliyatmono-kembali-majupilkada-karanganyar.html. 
Pendaftaran pasangan calon Yuli-Rober di hari terakhir tersebut dinyatakan diterima oleh KPU Karanganyar. Dengan ini bisa dipastikan hanya terdapat satu pasangan calon yang mendaftar pada pilkada Karanganyar sehingga KPU Karanganyar harus menunda tahapan dan membuka perpanjangan pendaftaran. ${ }^{11}$ Perlu diingat bahwa YuliRober diusung oleh gabungan partai politik yang terdiri dari delapan partai politik dari sembilan partai politik yang memiliki kursi di DPRD Kabupaten Karanganyar, dengan jumlah kursi sebanyak 39 kursi dari total keseluruhan kursi sebanyak 45 kursi DPRD Kabupaten Karanganyar, yaitu Partai Golkar, PDIP, PKB, Gerindra, PAN, Partai Hanura, PPP, dan Partai Demokrat, serta menyisakan PKS yang memiliki 6 kursi tidak mengusung pasangan calon.

Kemudian, KPU Karanganyar membuka perpanjangan pendaftaran selama tiga hari. Pada hari terakhir perpanjangan pendaftaran, bakal pasangan H. Rohadi Widodo, S.P.-Ida Retno Wahyuningsih, S.E. resmi mendaftar yang diusung oleh PKS dan Partai Gerindra. Pendaftaran dilakukan oleh Pimpinan Partai PKS Kabupaten Karanganyar dan Pengurus perwakilan dari Dewan Pimpinan Pusat Partai Gerindra. Hal ini awalnya memunculkan dilema bagi KPU Karanganyar dalam menerima pendaftaran Pasangan Calon Rohadi-Ida yang diusung oleh DPP Partai Gerindra yang dilakukan tanpa mencabut dukungan sebelumnya.

11 Mekanisme penundaan dan perpanjangan pendaftaran diatur dalam Peraturan KPU Nomor 3 Tahun 2017 tentang Pencalonan Pemilihan Gubernur dan Wakil Gubernur, Bupati dan Wakil Bupati, dan/atau Walikota dan Wakil Walikota. 
Namun, setelah pendaftaran pasangan calon telah mendapatkan respons dari KPU Karanganyar sebagaimana dibahas lebih lanjut pada tulisan ini, akhirnya dukungan Partai Gerindra terhadap pasangan calon lain sebelumnya dinyatakan tidak berlaku dan KPU Karanganyar menetapkan ada dua bakal pasangan calon bupati dan wakil bupati yang berhak untuk mengikuti tahapan selanjutnya, yaitu:

Tabel 1 Daftar Bakal Pasangan Calon Bupati dan Wakil Bupati pada Pemilihan Bupati dan Wakil Bupati Karanganyar Tahun 2018

\begin{tabular}{|c|c|c|c|}
\hline $\begin{array}{c}\text { Nomor Urut } \\
\text { Pendaftaran }\end{array}$ & Nama Bakal Pasangan Calon & Keterangan & $\begin{array}{r}\text { Parpol/Gabungan } \\
\text { Parpol Pengusung }\end{array}$ \\
\hline \multirow{2}{*}{1} & Drs. H. Juliyatmono, M.M. & Calon Bupati & \multirow{2}{*}{$\begin{array}{c}\text { Golkar, PDI Perjuangan, } \\
\text { Hanura, PKB, PPP, PAN }\end{array}$} \\
\cline { 2 - 3 } 2 & H. Rober Christanto, S.E. & Calon Wakil Bupati & \multirow{2}{*}{ PKS, Gerindra } \\
\cline { 2 - 3 } & H. Rohadi Widodo, S.P. & Calon Bupati & \\
\hline
\end{tabular}

Sumber : KPU Kabupaten Karanganyar

Juliyatmono bukan nama asing di Kabupaten Karanganyar. Dia adalah Bupati terpilih pada pilkada Karanganyar 2013 didampingi oleh Rohadi Widodo selama periode 2013-2018. Perjalanan politiknya bisa dikatakan mulus, setelah beberapa kali menjabat sebagai anggota DPRD Kabupaten Karanganyar dan terpilih menjadi Bupati pada tahun 2013. Pada pilkada serentak tahun 2018, ia menggandeng Rober Christanto seorang kader PDIP yang menjabat sebagai anggota DPRD Karanganyar yang masih aktif. 
Sedangkan Rohadi Widodo, wakil Juliyatmono yang awalnya digadang-gadang akan maju bareng lagi di laga pilkada Karanganyar 2018 harus menelan pil pahit karena "diceraikan” oleh Juliyatmono. Politisi PKS itu akhirnya menggandeng Ida Retno Wahyuningsih seorang pengusaha asal Kecamatan Kebakramat. Mereka mendaftarkan diri sebagai bakal pasangan calon bupati dan wakil bupati ke KPU Karanganyar pada kesempatan yang berbeda. Pasangan JuiiyatmonoRober Christanto mendaftar pada masa pendaftaran, sedangkan pasangan Rohadi Widodo-Ida Retno Wahyuningsih mendaftar pada masa perpanjangan.

Sikap pragmatis partai politik di Kabupaten Karanganyar dapat dikategorikan sebagai salah satu bukti nyata "The End of Ideology" seperti apa yang dikemukanan Fukuyama (1992) lebih dari dua dekade lalu atas perkembangan masyarakat dunia dewasa ini. Pragmatisme tidak hanya terjadi pada proses koalisi, tetapi juga terlibat dalam calon yang diajukan hanya mengedepankan elektabilitas dan popularitas semata. Tidak banyak partai politik yang melaksanakan fungsinya untuk melakukan kaderisasi. Partai menggunakan pertimbangan pragmatis untuk calon yang diusungnya (Fukuyama, 1992).

Padahal sebenarnya, koalisi merupakan keniscayaan yang tidak bisa dihindari dalam proses bangsa yang menganut sistem multipartai. ${ }^{12}$ Koalisi dapat dimaknai sebagai satu jalinan kerja sama yang dibentuk antara dua atau lebih pihak yang berkongsi kepentingan

12 Arend Lijphart. 2009. Sistem Pemerintahan Parlementer dan Presidensial. Jakarta: PT Raja Grafindo. Hal 51. 
untuk mencapai suatu tujuan yang sama. ${ }^{13}$ Muller dan Storm dalam Ambardi (2009) menggambarkan dilema partai politik dalam membuat berbagai keputusan yang melibatkan konflik tujuan. Pilihan berkoalisi terkadang mengabaikan ideologinya. Padahal sebenarnya, koalisi partai pengusung sangat menentukan kekuatan politik pemilu. Koalisi yang baik adalah koalisi dengan partai lain yang memiliki kesamaan ideologis. Semakin sama idelogi politiknya semakin awet koalisi yang terbentuk dan begitu juga sebaliknya. ${ }^{14}$

\section{KEPUTUSAN KPU DALAM MENGHADAPI PRAGMATISME PARTAI POLITIK SAAT PENCALONAN}

Perubahan komposisi pencalonan yang dilakukan oleh partai politik pada Pilkada Karanganyar 2018 berlangsung sangat cepat. Belum adanya regulasi yang mengatur tentang perubahan komposisi partai pengusung pasangan calon yang telah diterima pendaftarannya kemudian mengusung pasangan calon lain pada saat perpanjangan pendaftaran memunculkan dilema tersendiri bagi KPU Karanganyar. Dalam jangka waktu tiga hari, KPU Karanganyar mempersiapkan segala kemungkinan yang akan terjadi, termasuk memutuskan untuk menerima pendaftaran bakal pasangan calon Rohadi-Ida yang diusung oleh salah satunya partai Gerindra yang telah lebih dulu mendukung

13 Boissevain dalam Nidzammudin. Ahmad Sulaiman. 2006. Pakaian dalam Politik Sarawak. Bangi: Universiti Kebangsaan Malaysia. Hal 33.

14 Arend Lijphart. 2009. Sistem Pemerintahan Parlementer dan Presidensial. Jakarta: PT Raja Grafindo. Hal 51. 
pasangan calon Yuli-Rober. Keputusan ini yang kemudian menjadi sorotan.

Berdasarkan wawancara dengan komisioner KPU Karanganyar, Muhammad Maksum, KPU Karanganyar telah melakukan kajian dan tindakan hingga akhirnya berani mengambil keputusan untuk menerima pendaftaran Rohadi Widodo-Ida Retno Wahyuningsih. Muhammad Maksum mengungkapkan:

"KPU Karanganyar telah melakukan persiapan apabila desas-desus perubahan komposisi koalisi partai pengusung pasangan calon bupati dan wakil bupati Karanganyar benar-benar terjadi. Kami sudah mengantisipasi sebelumnya dengan melakukan koordinasi dan konsultasi kepada KPU RI dan meminta pendampingan dari KPU Jawa Tengah. Pada masa penundaan tahapan dan sosialisasi perpanjangan pendaftaran, kami telah mengkaji beberapa peraturan yang memiliki relevansi dengan kasus di Kabupaten Karanganyar ini. Namun, semua itu tidak terlepas dari koordinasi KPU Karanganyar dengan mitra kerja sesama penyelenggara pemilu di Kabupaten Karanganyar, yaitu Panwas Kabupaten Karanganyar." (Maksum, 2019).

Penjelasan mengenai tahapan dalam proses persiapan hingga pengambilan keputusan, KPU Karanganyar sebagai respons dalam menghadapi polemik pencalonan, sebagaimana disampaikan oleh anggota KPU Divisi Teknis KPU Karanganyar adalah sebagai berikut: ${ }^{15}$

15 Sumber diolah dari hasil penjelasan saat wawancara dengan Anggota KPU Divisi Teknis, Muhammad Maksum, S.Sos., MM. yang dilakukan pada tanggal 9 Desember 2019 dan dokumentasi KPU Karanganyar. 


\section{Menunda Tahapan Pilkada}

Setelah dipastikan hanya terdapat satu pasangan calon bupati dan wakil bupati yang mendaftar, KPU Karanganyar mengambil langkah menunda tahapan pilkada Karanganyar 2018 dengan menerbitkan Keputusan KPU Kabupaten Karanganyar Nomor_27/PP.02.3-Kpt/3313/ KPU-Kab/I/2018. Lalu, mengubah Keputusan KPU Karanganyar tentang Penetapan Pedoman Teknis Tahapan, Program, dan Jadwal Pemilihan Bupati dan Wakil Bupati Karanganyar Tahun 2018, dan melaksanakan sosialisasi selama tiga hari kemudian membuka lagi pendaftaran bakal pasangan calon selama tiga hari setelahnya. ${ }^{16}$

\section{Melakukan Sosialisasi mengenai Perpanjangan Pendaftaran}

Sosialisasi dilakukan kepada masyarakat dengan tujuan agar masyarakat mengetahui bahwa bakal pasangan calon bupati dan wakil bupati untuk Pilkada Karanganyar 2018 hanya terdapat satu pasangan calon yang mendaftar. ${ }^{17}$ Sosialisasi kepada khalayak umum dilakukan dengan membuat pengumuman nomor 103/PL.03.2-Pu/3313/KPUKab/I/2018 tentang Perpanjangan Pendaftaran Bakal Pasangan Calon

16 Lihat ketentuan Pasal 102 ayat (1) Peraturan KPU Nomor 3 Tahun 2017.

17 Hasil wawancara dengan sekretaris kelompok kerja Pendaftaran dan Penetapan Pasangan Calon Bupati dan Wakil Bupati Karanganyar Tahun 2018 sekaligus Kasubbag Hukum Smaragung Wibowo, SH, MM, pada masa sosialisasi perpanjangan pendaftaran KPU Karanganyar memanfaatkan tahapan ini untuk menyebarkan secara luas informasi kepada masyarakat umum dan kepada partai poltik tingkat Kabupaten Karanganyar dan melakukan kajian atas aturan yang berlaku sekaligus berkoordinasi dengan berbagai pihak. 
Bupati dan Wakil Bupati pada Pemilihan Bupati dan Wakil Bupati Karanganyar Tahun $2018 .^{18}$

\section{Koordinasi dan Konsultasi kepada KPU RI melalui KPU Provinsi Jawa Tengah}

Kurangnya sisa kursi partai politik di DPRD Kabupaten Karanganyar yang bisa mengusung pasangan calon dan munculnya desas-desus akan adanya perubahan komposisi dukungan partai politik kepada salah satu pasangan calon, KPU Karanganyar mengambil langkah koordinasi dengan KPU RI melalui KPU Jawa Tengah. Ada empat petimbangan KPU Provinsi menyarankan untuk menerima pendaftaran Rohadi-Ida, di antaranya: ${ }^{19}$

Pertama, melalui penundaan tahapan dan sosialisasi pendaftaran kepada masyarakat sehingga masyarakat mengetahui bahwa hanya terdapat satu pasangan calon yang mendaftar telah sesuai dengan peraturan KPU Nomor 3 Tahun 2017 yang bermakna memberi kesempatan munculnya bakal pasangan calon yang lain.

Kedua, dilakukan sesuai mekanisme pencalonan sesuai ketentuan Pasal 6 Peraturan KPU Nomor 3 Tahun 2017, sebagaimana diubah

18 Pasal 14 Huruf C UU Nomor 1 Tahun 2015 menyebutkan bahwa KPU Kabupaten/Kota wajib menyampaikan semua informasi penyelenggaraan Pemilihan Bupati dan Walikora kepada masyarakat.

19 Pertimbangan didasarkan atas Surat KPU RI Nomor: 97/PL.03.2/06/KPU/I/2018 tanggal 26 Januari 2018 yang berisi penjelasan tentang pencalonan kepala daerah di Karanganyar pada masa perpanjangan pendaftaran. Dasar surat tersebut dijadikan pedoman bagi KPU Provinsi Jawa Tengah untuk melakukan asistensi sekaligus memberikan penjelasan kepada KPU Karanganyar melalui surat Nomor: 190/PL.03.2-SD/33/Prov/I/2018 tanggal 30 Januari 2018 perihal Penjelasan Perbaikan Syarat Pencalonan dan Syarat Calon Pemilihan Bupati dan Wakil Bupati Karanganyar Tahun 2018. 
dengan Peraturan KPU Nomor 15 Tahun 2017, pencabutan dukungan partai politik terhadap bakal pasangan calon yang telah diterima pendaftarannya tidak dibenarkan, tetapi dalam hal hanya terdapat satu pasangan calon sebagaimana dimaksud dalam Pasal 102 Peraturan KPU Nomor 3 Tahun 2017 dan sebagaimana diubah dengan Peraturan KPU Nomor 15 Tahun 2017, pencabutan dukungan partai politik diperbolehkan.

Ketiga, mekanisme pengalihan dukungan partai politik terhadap bakal pasangan calon yang telah diterima pendaftarannya, dapat dilakukan tanpa melalui persetujuan bakal pasangan calon atau gabungan partai politik sebelumnya. Sedangkan pendaftaran bakal pasangan calon baru dapat diterima sepanjang memenuhi ketentuan Pasal 39 Peraturan KPU Nomor 3 Tahun 2017 sebagaimana diubah dengan Peraturan KPU Nomor 15 Tahun 2017 dan bagi bakal pasangan calon yang telah diterima pendaftarannya tetap sah.

Keempat, karena dilakukan dalam waktu yang mendesak, maka sesuai peraturan KPU Nomor 3 Tahun 2017 penyesuaian terhadap dokumen pencalonan yang belum sesuai dapat dilakukan pada masa perbaikan. Di samping itu, KPU RI juga menerbitkan payung hukum peristiwa tersebut yang tertuang dalam Surat Nomor 17/PL.03.2SD/06/KPU/I/2018 tanggal 5 Januari 2018 perihal penjelasan beberapa ketentuan pencalonan pemilihan tahun 2018, yang menjelaskan tentang ketentuan yang harus dilakukan apabila pencalonan kepala daerah 
mengalami permasalahan seperti yang dialami oleh KPU Kabupaten Karanganyar dalam menerima pasangan calon Rohadi-Ida. ${ }^{20}$

\title{
4. Berkoordinasi dengan Panwas Kabupaten Karanganyar
}

\author{
Untuk menjamin keabsahan dan kelancaran proses pendaftaran
} pada masa perpanjangan, dilakukan koordinasi dengan panwas kabupaten sebagai mitra kerja penyelenggara pemilu tingkat Kabupaten Karanganyar. ${ }^{21}$ Koordinasi dengan panwas melalui surat Nomor: 20/PL.03.2-SD/3313/KPU-Kab/I/2018 tanggal 11 Januari 2018 yang pada pokoknya memberitahukan bahwa tahapan pelaksanaan

20 Surat Nomor 17/PL.03.2-SD/06/KPU/I/2018 menjelaskan dua poin penting, yaitu pertama, ketentuan pengambilalihan kewenangan oleh DPP Partai tingkat pusat, berdasarkan ketentuan Pasal 39 Ayat (2) Peraturan KPU Nomor 3 Tahun 2017, disyaratkan bahwa pengurus partai politik tingkat pusat harus menerbitkan Surat Keputusan perihal pengambilan proses pencalonan di daerah tersebut. Kedua, seluruh dokumen wajib ditandatangani oleh ketua umum atau sebutan lain dan sekretaris jenderal atau sebutan lain. Lalu, dijelaskan pula mengenai pasangan calon yang dicalonkan oleh gabungan partai politik dan hanya sebagian partai politik yang pendaftarannya diambil alih oleh pengurus partai poltik tingkat pusat, penandatanganan seluruh dokumen syarat pencalonan dapat dilakukan dengan cara: 1) ketua umum dan sekretaris jenderal partai politik yang mengambil alih proses pendaftaran menandatangani seluruh dokumen syarat pencalonan pasangan calon yang bersangkutan, 2) seluruh dokumen yang telah ditandatangani, discan dan disampaikan kepada helpdesk KPU RI melalui Liaison Officer (LO)/petugas penghubung partai poltik tingkat pusat kemudian di-email ke KPU Provinsi atau KPU Kabupaten/Kota oleh petugas helpdesk Pilkada KPU RI, 3) setelah menerima email dimaksud, petugas pendaftaran KPU Provinsi atau KPU Kabupaten/Kota mencetak dokumen tersebut kemudian diserahkan ke tim kampanye pasangan calon yang bersangkutan, 4) setelah menerima dokumen tersebut, tim pasangan calon menyerahkan kepada ketua dan sekretaris partai poltik yang pendaftarannya tidak diambil alih oleh pengurus partai politik tingkat pusat untuk menandatangani dokumen pencalonan. Kemudian, pengurus partai politik tingkat pusat menerbitkan surat tugas yang menunjuk personil pengurus partai politik tingkat pusat yang ditugaskan untuk mengurus dokumen persyarayat dalam pendaftaran pasangan calon.

21 Ketentuan Pasal 77 Ayat (1) Huruf a Angka 2 menyebutkan bahwa tugas dan wewenang panwaslu Kabupaten/Kota adalah mengawasi tahapan penyelenggaraan pemilu di wilayah Kabupaten/Kota dalam kaitannya dengan pencalonan bupati/walikota. 
pilkada Karanganyar 2018 ditunda sementara waktu sampai dengan dibukanya kembali perpanjangan pendaftaran. Koordinasi dengan panwas kabupaten berlanjut saat pengawasan intensif di kantor KPU Karanganyar selama masa sosialisasi, serta pendampingan pada saat penerimaan pendaftaran.

\section{Melakukan Kajian Normatif}

Belum diaturnya mengenai perubahan komposisi partai pengusung pasangan calon pada masa perpanjangan mengakibatkan penyelenggara pemilu harus berhati-hati dalam pengambilan keputusan. Untuk memperkuat argumen dan ketepatan pengambilan keputusan, KPU melakukan kajian terhadap aturan-aturan yang berkaitan dengan pencalonan kepala daerah dan mencermati berbagai literasi yang berkaitan dengan penyelenggaraan pilkada langsung, serta mengumpulkan regulasi yang tidak bertentangan dengan kasus perubahan komposisi partai politik pengusung pada saat pencalonan kepala daerah. Kajian normatif dilakukan dengan mempelajari penjelasan Pasal 102 Peraturan KPU Nomor 15 Tahun 2017 dengan simulasi sebagai berikut: ${ }^{22}$

a. Jika terdapat gabungan partai politik A, partai politik B, dan partai politik $\mathrm{C}$ yang mengusung dan mendaftarkan pasangan calon X dan setelah dilakukan penelitian terhadap kelengkapan dan keabsahan syarat pencalonan dan kelengkapan syarat calon, pasangan calon yang bersangkutan dinyatakan

22 Simulasi ini berdasarkan atas penjelasan Surat Nomor 53/PL.03.2-SD/06/KPU/I/2018, Tanggal 15 Januari 2018 yang berisi penjelasan teknis tentang dokumen syarat pencalonan dan syarat calon pada masa perpanjangan pendaftaran yang dilakukan oleh partai pengusung yang pencalonannya telah diterima KPU. 
memenuhi syarat, lalu terdapat partai politik D dan partai politik E yang belum mendaftar pada masa pendaftaran, dan jika perolehan kursi atau suara sah kedua partai politik tersebut digabungkan masih mencukupi untuk mendaftarkan pasangan calon, maka pada masa perpanjangan pendaftaran, komposisi partai pengusung pasangan calon $\mathrm{X}$ tidak dapat diubah.

b. Jika terdapat partai politik A, partai politik B, dan partai politik $\mathrm{C}$ yang mendaftarkan pasangan calon $\mathrm{X}$ dan setelah dilakukan penelitian terhadap kelengkapan dan keabsahan syarat pencalonan dan kelengkapan syarat calon, pasangan calon yang bersangkutan dinyatakan memenuhi syarat, lalu terdapat partai poltik D dan partai politik E yang belum mendaftarkan pada masa pendaftaran, dan jika perolehan kursi atau suara sah kedua partai politik jika digabungkan tidak mencukupi untuk mendaftarkan pasangan calon, maka pada masa perpanjangan pendaftaran pasangan calon $\mathrm{X}$ dapat mendaftar kembali dengan komposisi partai politik yang berbeda (bukan komposisi partai politik sebelumnya (partai A, partai B, dan partai C) dan kemungkinan bagi partai D dan partai $\mathrm{E}$ untuk bergabung dengan partai politik yang mendaftarkan pasangan calon $\mathrm{X}$ atau mendaftarkan pasangan calon Y dengan membentuk gabungan partai poltik baru dengan salah satu atau lebih partai poltik pengusung pasangan calon $\mathrm{X}$ yang menarik dukungannya.

\section{Mengambil Keputusan untuk Menerima Pendaftaran Pasangan Rohadi-Ida}

Melalui rapat pleno di bawah supervisi KPU Provinsi Jawa Tengah, KPU Karanganyar memberikan tanda terima Model TT.1 KWK dan 
lampirannya kepada pasangan calon Rohadi-Ida sebagai bukti bahwa pendaftarannya telah diterima. 23

Keputusan itu dirumuskan berdasarkan koordinasi bersama dengan beberapa pihak dan telah melalui kajian normatif yang menghasilkan pilihan alternatif untuk menciptakan kebijakan publik. Dapat dikatakan, kebijakan KPU Karanganyar tersebut merupakan kebijakan politik. Dalam konteks ini, meskipun keputusan KPU diambil berdasarkan pertimbangan normatif, namun dapat berimplikasi terhadap hak politik masyarakat (publik) yang secara tidak langsung diselamatkan oleh organisasi ini.

Keputusan ini juga berimplikasi terhadap tahapan pilkada yang lain, karena tahapan yang telah ditetapkan oleh KPU RI harus dilaksanakan oleh KPU Kabupaten/Kota dengan tepat waktu. ${ }^{24}$ Keputusan yang diambil secara cepat dan tepat saat menghadapi perilaku pragmatis partai politik di Kabupaten Karanganyar merupakan konsekuensi dari kewajiban penyelenggara pemilu untuk melaksanakan pemilihan secara tepat waktu. Bukan tanpa alasan, karena masing-masing tahapan penyelenggaraan pemilihan berisi rangkaian tugas yang kompleks, memiliki jadwal pelaksanaan yang ketat dan jika satu tahapan terganggu maka akan berimplikasi pada tahapan yang lain sehingga keputusan harus segera diambil.

23 TT.1 KWK memuat dokumen dalam bentuk hardfile dan softfile yang akan diperiksa dan akan dicatat dalam lampiran tanda terima. Sedangkan Lampiran Model TT.1 KWK memuat kelengkapan dokumen syarat pencalonan dan syarat bakal calon bupati dan wakil kepala daerah.

24 Pasal 14 Huruf a UU Nomor 1 Tahun 2015. 
Di sisi lain, untuk memecahkan masalah yang berkaitan dengan perilaku pragmatis partai politik pada Pilkada Karanganyar 2018 menjadi tanggung jawab KPU Karanganyar, karena KPU Karanganyar menjadi satu-satunya lembaga yang memegang kekuasaan untuk mengendalikan perhelatan politik di Karanganyar. Kekuasaan itu, menurut Richard L. Daft adalah sebagai "Penggunaan kekuasaan guna memengaruhi keputusan dalam rangka memperoleh hasil yang diharapkan" (Daft, 2010). Penggunaan kekuasaan tersebut diartikan secara politik dilihat sebagai proses organisasi yang alamiah demi menyelesaikan perbedaan di antara kelompok kepentingan dalam organisasi. Politik dalam proses tawar-menawar dan negosiasi yang digunakan untuk mengatasi konflik dan perbedaan pendapat. Dalam cara pandang ini, sama dengan pembangunan koalisi dalam prosesproses pembuatan keputusan. Politik ini bersifat netral tidak perlu membahayakan organisasi (Daft, 2010).

Untuk itu, segala kebijakan KPU dituangkan dalam sebuah keputusan. Hal ini karena organisasi dan penyelengaraan pemilu merupakan perangkat kerja yang kompleks dan melibatkan banyak hak-hal detail. Biasanya upaya ini kerap dispesifikasikan ke dalam hukum tertulis dan regulasi ketimbang hanya melalui tradisi tidak tertulis. Hukum dan regulasi tertulis cenderung lebih memberi kepastian, visibiltas, dan transparansi, juga lebih mudah untuk dikaji ulang dalam konteks yudisial dan lebih mudah diakses oleh pihakpihak yang berkepentingan, termasuk para pemilih. Kepastian legal yang didapatkan melalui penjabaran yang detail mengenai proses 
pemilu di dalam undang-undang, dibantu oleh otoritas konstitusional, akan membantu meningkatkan kepercayaan publik terhadap aspek konsistensi, kesetaraan, dan keadilan di dalam proses penyelenggaraan pemilu, juga memberikan kesempatan yang besar bagi perbaikan di kemudian hari. ${ }^{25}$

Pada akhirnya, kebijakan yang dituangkan dalam sebuah keputusan tersebut dapat mengikat semua pihak yang terlibat dalam proses pemilu, pemilih, partai politik dan kandidat, media, dan kelompok pemantau. Oleh karena itu, keputusan itu dibuat harus konsisten dengan konstitusi dan Undang-Undang pemilu yang ada. ${ }^{26}$

Keberanian pengambilan keputusan ini tidak terlepas dari konstruksi kelembagaan KPU Karanganyar sebagai penyelenggara pemilu tingkat bawah (tingkat kabupaten/kota) dalam melaksanakan fungsi komunikasi politik secara vertikal melalui komunikasi dan koordinasi kepada KPU Provinsi dan KPU RI. Hal ini sesuai dengan amanat Pasal 22E UUD 1945, dimana dalam penyelenggaraan pilkada, KPU RI menjadi regulator dan pengawas internal penyelenggaraan pilkada oleh KPU Provinsi dan KPU Kabupaten/Kota.

\section{ANALISIS KEPUTUSAN KPU KARANGANYAR DALAM MENERIMA PENCALONAN ROHADI-IDA}

Keputusan yang diambil oleh KPU Karanganyar dalam tahapan pencalonan menurut konsep International IDEA harus

25 Alan Wall, dkk. 2006. Desain Penyelenggaraan Pemilu Buku Pedoman International IDEA. Hal 46.

26 Ibid. Hal 67. 
dapat dipertanggung-jawabkan dan mengikat semua pihak yang berkepentingan dalam proses demokrasi tingkat lokal. Dengan kata lain, pengambilan keputusan yang ditetapkan dapat diterima oleh pasangan calon, panitia pengawas pemilu dan pihak terkait. Oleh karena itu, analisis dalam beberapa aspek terhadap keputusan KPU Karanganyar tersebut diurai dalam bagian ini.

Ditinjau dari sisi penyelenggara pemilu, Lembaga Penyelenggara Pemilu (LPP) di Indonesia yang dilaksanakan oleh KPU yang didesain untuk bekerja dengan mengutamakan prinsip-prinsip penyelenggara pemilu. Menurut International IDEA, ada tujuh prinsip yang melekat pada sebuah penyelenggaraan pemilihan umum untuk melaksanakan pemilu yang baik, yaitu: ${ }^{27}$ integritas, imparsialitas, independensi, transparansi, efisiensi, berorientasi pada pelayanan, dan profesionalisme. Kasus yang terjadi di Kabupaten Karanganyar menjadi penting untuk mendalami prinsip profesionalisme, karena prinsip ini sangat urgen dalam melihat bagaimana sebuah lembaga penyelenggara pemilu bertindak sesuai tugas dan wewenangnya. Salah satu indikator sederhana profesionalisme penyelenggara pemilu adalah cepat tanggap terhadap masalah pemilu yang kedatangannya sulit terprediksi. ${ }^{28}$ Untuk itu, kepatuhan terhadap kerangka legislatif, termasuk semua regulasi,

27 Alan Wall, Dkk. 2006. Desain Penyelenggara Pemilu diterjemahkan oleh Perludem dari International IDEA Electoral Management Design: The International IDEA Handbook, Stockholm: Swedia. Hal 163-164.

28 Moh Sugihatyadi dan Joni Rahardjo. 2015. "Menakar Profesionalisme Penyelenggara Pemilu 2014 di Kota Garam Analisis Kepemimpinan, Intergitas, Independensi, dan Kompetensi Kepemiluan.” Jurnal Addin, Vol 9 No 1. Hal 109-110. 
prosedur, dan pedoman pemilu merupakan prasyarat yang harus dipenuhi untuk memiliki penyelenggara pemilu yang profesional. ${ }^{29}$

Kasus yang terjadi di Kabupaten Karanganyar pada saat pencalonan kepala daerah Pilkada Serentak tahun 2018, KPU Karanganyar dituntut untuk bekerja secara profesional untuk memecahkan masalah yang datangnya tidak terpredisksi, dan dalam waktu yang singkat harus mengambil keputusan secara bijak dengan memperhatikan normanorma yang berlaku. Pengambilan keputusan ini dilaksanakan sesuai kerangka regulatif berdasarkan tugas dan wewenang KPU Kabupaten/ Kota sebagaimana diamanatkan dalam Undang-Undang Nomor 15 Tahun 2011. ${ }^{30}$ Pengambilan keputusan tersebut dilaksanakan sesuai dengan mekanisme pengambilan keputusan melalui rapat pleno yang dihadiri oleh seluruh komisioner KPU Kabupaten Karanganyar. ${ }^{31}$

Hasil keputusan KPU Karanganyar tersebut dapat menunjang pelaksanaan kontestasi politik di Kabupaten Karanganyar. Secara teknis operasional, KPU Karanganyar telah mengambil langkahlangkah strategis yang responsif terhadap fenomena yang upredictable pada penyelenggaraan pilkada. Keputusan itu berimplikasi terhadap pemenuhan hak politik bagi masyarakat sebagai pemilih, dan kepada

29 Alan Wall, Dkk. 2006, Desain Penyelenggara Pemilu diterjemahkan Oleh Perludem dari International IDEA Electoral Management Design: The International IDEA Handbook. Stockholm: Swedia. Hal 163.

30 Pasal 10 Ayat (3) Huruf e UU Nomor 15 Tahun 2011 menyebutkan bahwa tugas dan wewenang KPU Kabupaten/Kota dalam penyelenggaraan pemilihan bupati/walikota adalah mengoordinasikan, menyelenggarakan, dan mengendalikan semua tahapan penyelenggaraan pemilihan bupati/walikota berdasarkan ketentuan peraturan perundang-undangan dengan memperhatikan pedoman dari KPU dan/atau KPU Provinsi.

31 Pasal 30 UU Nomor 15 Tahun 2011. 
pasangan calon karena telah diberikan kesempatan yang sama untuk terlibat dalam kontestasi tingkat lokal. Menurut Collaborative for Academic, Social, and Emotional Learning (CASEL), keputusan harus memperhatikan nilai dan norma yang bisa diterima oleh orang lain atau sekumpulan orang dan bisa dipertanggungjawabkan terkait apa yang sudah diputuskannya. ${ }^{32}$ Secara regulatif, keputusan KPU Karanganyar dapat dipertanggungjawabkan kepada masyarakat sebagai pemegang kedaulatan tertinggi dalam demokrasi.

Sejalan dengan itu, Pratiwi Tedjo mengatakan bahwa dalam pengambilan keputusan politik, hal utama yang dibutuhkan adalah beberapa pedoman, beberapa kriteria yang relevan, untuk menarik kesimpulan serta untuk menghindari penyimpangan tujuan ketika hendak menghasilkan keputusan politik yang berdampak pada masyarakat (Tedjo, 2019). Kebijakan KPU Kabupaten Karanganyar telah memuat elemen penting tentang kebijakan negara ( $p u b l i c$ policy), seperti yang dikemukanan oleh Irfan Islamy (2002), yaitu kebijakan negara itu dalam bentuk perdananya berupa penetapan tindakantindakan pemerintah; kebijakan negara itu tidak cukup hanya dinyatakan tetapi dilaksanakan dalam bentuk yang nyata; kebijakan untuk melakukan atau tidak melakukan sesuatu perlu dilandasi dengan maksud dan tujuan tertentu; kebijakan negara harus ditujukan untuk kepentingan masyarakat (Islamy, 2002).

Hasil Keputusan KPU Karanganyar tersebut juga dapat dianalisis berdasarkan kepentingan penyelenggaraan pemilu, yang mencakup tiga

32 https://www.landmarkoutreach.org/strategies/responsible-decision-making/. 
dimensi waktu sekaligus, yaitu 1) waktu yang lalu (the past) pada saat di mana berbagai masalah berkembang, informasi dikumpulkan, dan kebutuhan akan keputusan dirasakan. 2) waktu sekarang (the present) pada saat di mana alternatif-alternatif ditemukan dan pilihan diambil. 3) waktu yang akan datang (the future) pada saat di mana keputusan dilaksanakan dan dievaluasi (Reksohadiprodjo \& Handoko, 1992). Hasilnya, KPU Kabupaten Karanganyar telah memperhatikan tiga prasyarat dimensi waktu, yaitu memperhatikan fenomena yang pernah terjadi, kebutuhan alternatif saat ini, dan memperhatikan kebutuhan kepastian hukum untuk pilkada yang akan datang.

Di sisi lain, keputusan KPU karanganyar tersebut juga dapat dilihat dari peran penyelenggara pemilu untuk menyelamatkan kontestasi politik tingkat lokal. Keputusan itu dipandang sebagai wujud nyata dari upaya sungguh-sungguh penyelenggara pemilihan yang tercantum dalam pertimbangan hukum Mahkamah Konstitusi dalam Putusan Nomor 100/PUU-XII/2015 yang menyebutkan bahwa Pemilihan Kepala Daerah dapat dilaksanakan apabila telah diusahakan dengan sungguh-sungguh untuk terpenuhi syarat paling sedikit dua pasangan calon. Pengaturan tersebut memungkinkan adanya perubahan komposisi gabungan partai politik yang pasangan calonnya telah diterima serta adanya pendaftaran pasangan calon baru dengan komposisi gabungan partai politik yang baru.

Berdasarkan ketentuan Pasal 39 Ayat (3) Huruf d Peraturan KPU Nomor 3 Tahun 2017 mengatur antara lain dalam hal pasangan calon didaftarkan oleh pengurus partai politik tingkat pusat karena 
pengurus partai politik tingkat daerah tidak melakukan pendaftaran, partai politik wajib memenuhi persyaratan salah satunya adalah menyertakan keputusan pimpinan partai politik tingkat pusat mengenai pengambilalihan wewenang partai politik tingkat provinsi atau tingkat kabupaten/kota dalam pendaftaran pasangan calon.

Dari penjelasan tersebut, mekanisme perubahan komposisi partai politik yang mendaftarkan pasangan calon kepala derah pada masa perpanjangan serta dilakukan dengan mekanisme pengambilalihan pendaftaran oleh partai politik tingkat pusat yang dilakukan oleh bakal pasangan calon bupati dan wakil bupati Karanganyar Rohadi-Ida dibenarkan sepanjang dilaksanakan sesuai dengan ketentuan tersebut.

Mengingat terdapat satu partai politik yang mendaftarkan dua pasangan calon yang berbeda, maka sesuai dari pasal 102 Peraturan KPU Nomor 15 Tahun 2017 yang telah disimulasikan dalam penjelasan, maka keputusan KPU Karanganyar dalam menerima pendaftaran bakal pasangan calon Rohadi-Ida adalah dibenarkan sehingga implementasi dari kebijakan ini telah sesuai dengan peraturan perundang-undangan yang berlaku dan selaras dengan aturan main pemilu.

Dalam perspektif lain, jika dilihat dari teori demokrasi, keputusan KPU Karanganyar dalam menerima pendaftaran pasangan Calon Rohadi-Ida menunjukkan hasil dari upaya untuk mempertahankan filosofi demokrasi, yang sejalan dengan pemikiran Joseph Schumpeter yang mengklaim bahwa dalam pelaksanaan demokrasi terdapat tiga prasyarat penting, yakni 1) kontestasi antar-individu untuk 
memperebutkan suara rakyat/pemilu yang adil, jujur, dan periodik, 2) kebebasan individu untuk berpartisipasi dalam kontestasi politik, baik sebagai pemilih maupun dipilih (kesetaraan), dan 3) prosedur/proses yang memungkinkan terjadinya sirkulasi pejabat publik:

\footnotetext{
"The democratic method is that institutional arrangement for arriving at political decision in which individuals acquire the power to decide by means of a competitive struggle for the people's vote. Metode demokratis adalah suatu prosedur kelembagaan untuk mencapai keputusan politik yang di dalamnya individu memperoleh kekuasaan untuk membuat keputusan melalui perjuangan kompetitif dalam rangka memperoleh suara Rakyat." (Schumpeter, 2003: 9).
}

Dengan demikian, KPU Karanganyar telah melakukan posedur tata kelola pemilu dengan mengakomodir seluruh prasyarat demokrasi, yaitu adanya kontestasi yang idealnya diikuti oleh minimal dua pasangan calon atau lebih untuk berkompetisi melalui proses pemilihan umum. Di samping itu, pelaksanaan kebijakan pemilu memberikan pengaruh positif terhadap kinerja penyelenggara pemilu dan kualitas pemilu. Kebijakan pemilu memberikan kepastian hukum terhadap aktor pemilu, yaitu penyelenggara pemilu, peserta pemilu, dan pemilih (Parhan, 2017).

Terakhir, ditinjau dari segi kelembagaan keputusan KPU Karanganyar merupakan wujud nyata kinerja lembaga yang profesional sebagai bagian dari pemerintah atau lembaga di tingkat Kabupaten/ Kota yang hadir untuk mengatur warganya agar tercipta keteraturan dan harmoni masyarakat yang memiliki berbagai macam masalah. Salah satu fungsi negara adalah fungsi regulatif yang harus menampung 
aspirasi dan masalah yang muncul pada masyarakat sehingga dalam proses pengambilan keputusan politik dan formulasi kebijakan harus benar-benar condong pada kepentingan masyarakat. Pada akhirnya, untuk menjamin hak dan kebebasan dalam bersuara dalam wadah pemilihan umum, maka keputusan dari KPU Karanganyar ini diharapkan dapat meningkatkan partisipasi masyarakat dalam pemilu.

\section{KESIMPULAN}

KPU Kabupaten/Kota sebagai penyelenggara pilkada harus selalu profesional dan cepat tanggap terhadap masalah pemilu yang kedatangannya sulit terprediksi, termasuk dalam hal pencalonan kepala daerah. KPU harus berani mengambil keputusan apabila partai politik bersikap pragmatis saat mengusung calon kepala daerah. Keputusan yang diambil harus memperhatikan norma-norma yang ada serta memberikan manfaat kepada kepentingan umum (publik).

Meskipun sikap pragmatis partai politik saat pencalonan telah terjadi sejak pilkada dilaksanakan secara langsung pada tahun 2005 sampai pilkada serentak pada tahun 2018, namun kasus yang terjadi di Kabupaten Karanganyar menjadi bukti bahwa perilaku pragmatis saat mengusung pasangan calon kepala daerah masih mengakar kuat dalam tubuh partai politik. Perubahan komposisi partai politik pengusung pasangan calon kepala daerah yang dilakukan setelah diterima pendaftarannya oleh KPU tanpa mencabut dukungan pasangan calon sebelumnya, seperti yang terjadi pada Pilkada Karanganyar 
2018, menempatkan KPU menjadi organisasi pemerintah yang harus memutuskan keputusan dilematis yang tidak sederhana.

Untuk menghadapi dan menyelesaikan permasalahan terkait sikap pragmatis partai politik tersebut, KPU dapat melakukan tindakan normatif yang dibenarkan oleh peraturan perundang-undangan yang berlaku. Pengambilan keputusan secara normatif menjadi pilihan alternatif untuk menyelesaikan polemik pencalonan karena setiap tahapan pelaksanaan pemilu diatur sedemikian rupa oleh Undangundang dan peraturan terkait lainnya. Keputusan tersebut juga harus dapat mengikat semua pihak yang terlibat dalam proses pemilu. Oleh karenanya, keputusan itu harus konsisten dengan konstitusi dan Undang-Undang pemilu yang ada.

KPU Kabupaten/Kota menjadi satu-satunya lembaga yang memegang kekuasaan untuk mengendalikan perhelatan politik di tingkat lokal memiliki tugas melaksanakan kebijakan yang ditetapkan oleh KPU RI. Oleh karena itu, KPU Kabupaten/Kota dalam menghadapi sikap pragmatis partai politik juga harus menunjukkan kepatuhan terhadap kerangka legislatif, termasuk semua regulasi, prosedur, dan pedoman pemilu yang telah ditetapkan oleh KPU RI.

Pada akhirnya, dapat disimpulkan bahwa meskipun pengambilan keputusan KPU dilakukan secara normatif, namun hasil dari keputusan itu dapat memengaruhi keberlangsungan kontestasi politik di tingkat lokal (Kabupaten/Kota). Dengan kata lain, keputusan KPU Kabupaten/ Kota tersebut dapat berimplikasi terhadap pemenuhan hak politik 
bagi masyarakat sebagai pemilih dan kepada pasangan calon karena telah diberikan kesempatan yang sama untuk terlibat dalam kontestasi tingkat lokal. Dengan demikian, pilkada dapat diselenggarakan sesuai dengan yang diidealkan.

Kemudian, perlu dicatat apabila dalam penyelenggaraan pilkada ke depan masih terkendala adanya pragmatisme partai politik dalam pencalonan, seperti yang terjadi di Kabupaten Karanganyar dan mengharuskan KPU memutuskan kebijakan pada waktu yang singkat, sedangkan regulasi yang mengatur tentang perubahan komposisi partai pengusung pada perpanjangan pendaftaran secara spesifik belum ada, maka prosedur pengambilan keputusan normatif oleh KPU Kabupaten/ Kota dapat menempuh langkah-langkah serupa yang diterapkan oleh KPU Karanganyar dengan memperhatikan aturan main pemilu. 


\section{REFERENSI}

Bambang, C. (2010). Otonomi Daerah. Jakarta: Pustaka Sinar Harapan.

Budi, A. (2020). Less Democracy, More Centralism: The Selection of Candidate by Golkar and PDI in Indonesia Subnational Executive Election, 2015-2020. Asien Journal of Politic Sience.

Bumi, M. C. (2016). Kompetisi Antara Petahana dala Pilkada Studi tentang Persaingan antara Walikota dan Wakil Walikota Periode 2010-2015 dalam Pilkada Kota Pasuruan Tahun 2015. Jurnai Unair.

Daft, R. L. (2010). Organization Theory and Design 10 Edition. Mason: Cengagde.

Fachri, A. M. (2005). Tinjauan Kritis terhadap Sistem Pemilihan dan Pencalonan Kepala Daerah. Jurnal Demokrasi, Vol. IV No. 2.

Fukuyama, F. (1992). The End of History and the Last Man. Free Press.

Harorld, L. D., \& Kaplam, A. (1970). Power and Society. New Haven: Yale University Press.

Hermayanti, A. R. (2018). Analisis Dinamika Politik Pencalonan Kepala Daerah dan Wakil Kepala Daerah pada Pilkada Serentak Tahun 2017.

IDEA, I. (2006). Electoral Management Design: The International IDEA Handbook. Sweden. 
Islamy, I. (2002). Prinsip-Prinsip Perumusan Kebijaksanaan Negara. Jakarta: Bina Aksara.

Kartono, K. (1996). Pendidikan Politik. Bandung: Mandar Maju.

Lestari, A., \& Rumesten, I. R. (n.d.). Faktor Penyebab Kehadiran Calon Tunggal dalam Pemilihan Kepala Daerah. Jurnal Fakultas Hukum Universitas Sriwijaya.

Lijphart, A. (2009). Sistem Pemerintahan Parlementer dan Presidensial. Jakarta: PT. Raja Grafindo.

Mayasari, U. (2018). Dinamika Pencalonan dan Pembatalan Ririn Kuswantari (Studi Perubahan Koalisi Partai Golongan Karya dan partai Persatuan Pembangunan pada Pilkada Kabupaten Pringsewu Tahun 2017).

Mulyadi. (1989). Organisasi, Teori, Struktur, dan Proses. Jakarta: Departemen Pendidikan Nasional Direktorat Jenderal Pendidikan Tinggi.

Nas, J. (2005). Demookrasi dan Demokratisasi: Konsep, Teori, dan Aplikasinya. Jurnal Wacana Indonesia, Vol. I No. 1.

Noor, F. (2014). Perilaku Politik Pragmatis dalam Kehidupan Politik Kontemporer: Kajian atas Menyurutnya Peran ideologi Politik di Era Reformasi. Jurnal Masyarakat Indonesia, Vol. 40 (1).

Parhan. (2017). Pengaruh Pelaksanaan Kebijakan Pemilu dan Manajemen Pemilu terhadap Kinerja Peneyelenggara Pemilu untuk Mewujudkan Kualitas Pemilu. Jurnal Publik. 
Parsons, W. (2008). Public Policy: An Introduction to the Theory and Practice of Policy Analysis (Tri Wibowo Budi Santoso, Penerjemah). Jakarta: Kencana Prenada Media Group.

Pearce, C. L., \& Conger, J. (2003). Shared Leadirship: Reframing the Hows and Whys of Leadership. United States of America: Sage Publications.

Reksohadiprodjo, S., \& Handoko, H. (1992). Organisasi Perusahaan: Teori, Struktur, dan Perilaku. Yogyakarta: BPFE.

Schumpeter, J. (2003). In Dahl, Shapiro, \& Cheibub. The Democracy Sourchebok Cambridge (pp. 5-11). MIT Press.

Sigler, J. A. (1977). The Legal Sources of Public. Lexington, Massashusetts, Toronto.

Siregar, H. (2018). Studi Kebijakan Politik: Aktor dan Isu dalam Proses Pengambilan Keputusan. Jurnal Communitarian, Vol. 1 No. 1.

Sugihatyadi, M., \& Rahardjo, J. (2015). Menakar Profesionalisme Penyelenggara Pemilu 2014 di Kota Garam: Analisis Kepemimpinan, Integritas, Independensi, dan Kompetensi Kepemiluan. Jurnal Addin, Vol 9 No 1.

Sukmajati, M. (n.d.). Kandidasi dalam Partai Politik di Indonesia. Https:// www.academia.edu/37338642/Kandidasi_Dalam_Partai_Politik_ Di_Indonesia.

Sulaeman , A. (2013). Demokrasi, Partai Politik, dan Pemilihan Kepala Daerah. Jurnal Cosmogov, Vol I No. 1. 
Sulaiman, A. (2006). Pakaian dalam Politik Sarawak. Bangi: Universiti Kebangsaan Malaysia.

Surbakti, R. (1922). Memahami Ilmu Poltik. Jakarta: Gramedia Widiasarana.

Syafaruddin, \& Anzizhan. (2008). Sistem Pengambilan Keputusan Pendidikan. Jakarta: Grasindo.

Tedjo, P. (2019). Demokrasi, Kebijakan Umum, dan Keputusan Politik. Jurnal Mimbar Administrasi, 116-134.

Wall, A., Ellis, A., Ayoub, A., Dundas, C. W., Joram, R., \& Staino, S. (2006). Desain Penyelenggara Pemilu: Buku Pedoman International IDEA diterjemahkan oleh Perludem dari International IDEA Electoral Management Design: The International IDEA Handbook. Swedia: Stockholm.

Widodo, S. (2016). Pemilu Kepala Daerah dalam Filosofi dan Normatif. Jurnal Magistra, No. 97 Tahun XVIII.

Zaafril, R. A. (2016). Peran Partai Politik dalam Pemilihan Kepala Daerah: Studi Upaya Partai Golkar dalam Memenangkan Pasangan Calon Juiyatmono-Rohadi di Pemilihan Kepala Daerah Kabupaten Karanganyar Tahun 2013. Jurnal Politik Muda, Vol. 5 No. 3. 


\section{PERATURAN PERUNDANG-UNDANGAN}

Undang-Undang Nomor 1 Tahun 2015 tentang Penetapan Peraturan Pemerintah Pengganti sebagaimana telah diubah beberapa kali, terakhir dengan Undang-Undang Nomor 10 Tahun 2016.

Peraturan Komisi Pemilihan Umum Nomor 3 Tahun 2017 sebagaimana diubah dengan Peraturan KPU Nomor 15 Tahun 2017.

Putusan Mahkamah Konstitusi Nomor 100/PUU-XII/2015.

\section{WAWANCARA}

Wawancara dengan Anggota KPU Karanganyar, Muhammad Maksum, S.Sos., MM. Tanggal 9 Desember 2019.

Wawancara dengan Kasubbag Hukum KPU Karanganyar, Smaragung Wibowo, SH, MM. Tanggal 10 Desember 2019.

\section{WEBSITE}

https://www.ceposonline.com/2018/01/20/ini-alasan-kpu-jayawijayakembalikan-berkas-paslon/.

https://infopemilu.kpu.go.id/pilkada2018.

https://www.kemendagri.go.id/berita/baca/16288/banyak-pasanganpetahana-pang-pecah-kongsi. 
https://www.landmarkoutreach.org/strategies/responsible-decisionmaking/.

https://www.merdeka.com/politik/didukung-8-partai-bupatijuliyatmono-kembali-maju-pilkada-karanganyar.html.

https://news.okezone.com/read/2018/01/10/512/1843091/calon-bupatikaranganyar-dipastikan-melawan-kotak-kosong. 